DOI: $10.17516 / 1997-1370-0778$

УДК $336.22 ; 338.12$

\title{
Impact of the 2020 Pandemic on Revenue from Various Taxes in the Russian Regions
}

\author{
Marina Yu. Malkina* \\ Lobachevsky State University of Nizhny Novgorod \\ Nizhny Novgorod, Russian Federation
}

Received 25.05.2021, received in revised form 15.06.2021, accepted 28.06.2021

\begin{abstract}
The article investigates the impact of the 2020 pandemic on tax revenues of Russian regions at the stages of their collection and allocation to regional budgets. To exclude the influence of the seasonal component and uneven receipts of various taxes to the budget, the moving annual tax revenues were calculated with a shift of one month. Based on these data for 2013-March 2020, linear time regressions were built and decomposed into 8 taxes and tax groups. These regressions were used to predict non-pandemic tax revenues for different regions in April-December 2020. The impact of the pandemic on the regional tax losses (gains) and their decomposition by sources was calculated through the deviation of the actual revenues from their predicted non-pandemic values on an accrual basis until the end of 2020 .

We found that the pandemic had led to losses of $13.9 \%$ of total tax revenues in the country and $6.2 \%$ of regional budgets' own tax revenues. The mining regions are the most affected by the pandemic. On the contrary, in some Far Eastern regions, there is an abnormal increase in tax collections. The largest contribution to the decrease in tax revenues at the consolidated and federal levels was made by the MET receipts; they fell sharply due to lower prices and volumes of oil and gas. However, the negative effect of this decrease at the federal level was dampened by stabilizing VAT receipts. Excise taxes played a positive role in mitigating pandemic risks. The tax distribution system has shown its equalizing function when allocating tax revenues to sub-federal budgets. The largest negative contribution to the change in regional tax revenues during the 2020 pandemic was made by the corporate income tax, while the negative impact of property taxes and special tax regimes turned out to be less significant. Personal income tax has proven to be the main damper of tax revenues at the regional level.

The results obtained are applicable to the management of the state fiscal revenues during pandemic crises.
\end{abstract}

Keywords: region, 2020 pandemic, tax revenue, regional resilience, decomposition.

The study was carried out within the framework of the basic part of the state assignment of the Ministry of Education and Science of the Russian Federation, project 0729-2020-0056.

\footnotetext{
(C) Siberian Federal University. All rights reserved

* Corresponding author E-mail address: mmuri@yandex.ru ORCID: 0000-0002-3152-3934
} 
Research area: economics.

Citation: Malkina, M. Yu. (2021). Impact of the 2020 pandemic on revenue from various taxes in the Russian Regions. J. Sib. Fed. Univ. Humanit. Soc. Sci., 14(7), 987-997. DOI: 10.17516/1997-13700778 .

\title{
Влияние пандемии 2020 года на доходы российских регионов от разных налогов
}

\author{
М.Ю. Малкина \\ Нижегородский государственньій университет \\ им. Н. И. Лобачевского \\ Российская Федерация, Нижний Новгород
}

\begin{abstract}
Аннотация. В статье исследуется влияние пандемии 2020 года на налоговые доходы российских регионов на этапе их сбора и распределения в региональные бюджеты. Для исключения влияния сезонной составляющей и неравномерности перечисления отдельных налогов в бюджет мы рассчитываем скользящие годовые значения налоговых доходов со сдвигом в 1 месяц. На основе этих данных за 2013март 2020 года построены линейные временные регрессии, а также проведена их декомпозиция по 8 налогам и налоговым группам. Эти регрессии положены в основу прогнозирования непандемических налоговых доходов регионов в апреледекабре 2020 года. Влияние пандемии на налоговые потери (выигрыши) регионов и их декомпозиция по источникам осуществлялись на основе расчета отклонений фактических доходов от прогнозных непандемических значений нарастающим итогом до конца 2020 года.

Выявлено, что пандемия привела к потерям 13.9 \% общих налоговых доходов в стране и $6.2 \%$ налоговых доходов территориальных бюджетов. Наиболее пострадавшими от пандемии оказались добывающие регионы. Между тем в некоторых дальневосточных регионах отмечался аномальный рост налоговых сборов. Наибольший вклад в снижение налоговых доходов консолидированного и федерального бюджета внес НДПИ, поступления по которому резко упали из-за снижения нефтегазовых доходов. Однако его негативный эффект на федеральном уровне демпфировался стабилизирующимися поступлениями по НДС. Некоторую положительную роль в смягчении пандемических рисков сыграли акцизы. При формировании доходов субфедеральных бюджетов проявилась выравнивающая функция системы распределения налогов. Наибольший отрицательный вклад в изменение налоговых поступлений в региональные бюджеты в условиях пандемии 2020 внес налог на прибыль, менее существенным оказалось отрицательное влияние налогов на имущество и поступлений от налоговых спецрежимов. Основным демпфером налоговых поступлений на региональном уровне стал НДФЛ.

Полученные результаты могут быть полезными для управления фискальными доходами государства в условиях пандемических кризисов.
\end{abstract}

Ключевые слова: регион, пандемия 2020 года, налоговые доходы, устойчивость регионов, декомпозиция. 
Исследование выполнено в рамках базовой части государственного задания Минобрнауки РФ, проект 0729-2020-0056.

Научная специальность: 08.00.00 - экономические науки.

\section{Introduction}

The 2020 pandemic, associated with the strict isolation of the population and the restriction of business activity, has had a significant impact on the economy of Russian regions. The federal and regional authorities employed various institutions, including fiscal incentives, to mitigate the consequences of this crisis. One of the most vulnerable to the pandemic was the budget sector, which faced both a drop in income and an increase in spending, which in turn created a number of short-term and longterm effects.

This article examines how the 2020 pandemic affected the tax revenues of Russian regions at the stages of their collection and distribution between the federal and sub-federal budgets. Using the developed methodology, we determine the predicted values of tax revenues in the absence of the pandemic and carry out their decomposition by source. After that, we assess the contribution of various taxes to the change in tax revenues in Russian regions during the crisis. Our study is designed to answer the question of why the fiscal systems of different regions showed unequal resilience to the 2020 pandemic, and how the tax distribution system influenced the spatial differences in the response of regional tax systems to this crisis.

\section{Literature Review}

Researchers study the fiscal effects of the 2020 pandemic: its impact on budgets revenues and expenditures at different levels, changes in their structure associated with structural shifts in production and consumption during the crisis (Darougheh, 2021; Gunay, Kurtulmuş, 2021). They consider the effects associated with limited mobility (Hoehn-Velasco et al., 2021), reduced business activity, and consumer hype in the early months of the pandemic (Keane, Neal, 2021).

Some scholars find evidence of the procyclical nature of fiscal policy amid pandemic uncertainty that is typical of highly indebted advanced countries (Chakrabarty, Roy, 2021). Other researchers focus on softening budget constraints in the pandemic as a result of increased public spending on health, social services and the introduction of fiscal incentives to support the population and business (Ershov, 2020). The result of such a policy is an increase in the budget deficit and public debt, which entails an inflationary threat in the future. Assessing the effectiveness of specific fiscal measures to combat the pandemic crisis, Makin and Layton (2021) show that the introduction of tax breaks and incentives during the pandemic is more expedient than increasing budget spending. Some studies apply a more detailed approach, linking revenue from different taxes during the 2020 pandemic to changes in sales across states (Chernick et al., 2020; Clemens, Veuger, 2020).

In addition, scientists explore the resilience of various regional economies to economic crises, including pandemics (Brada et al., 2021; Mikheeva, 2021), and the factors affecting resilience (Kolomak, 2020; Pietro et al., 2020). Few studies directly focus on the response of the Russian regional fiscal systems, their revenues and expenditures, and the level of debt to the 2020 pandemic (Klimanov et al., 2021). A number of researchers emphasize the importance of the sectoral structure of the economy (Kuznetsova, 2020), as well as the degree of openness and the level of economic diversification (Malkina, 2020) for a change in GRP and losses in fiscal revenues of regions in bad times. Investigating the spatial economic effects of the 2020 pandemic in Russia, Zubarevich (2021) notes that it has most affected the oil and gas producing regions, the regions of the automotive industry, and megalopolises with a developed service sector. The researchers also draw attention to the fact that the change in tax revenues in the Russian regions was influenced by both feder- 
al and regional policies of tax incentives and exemptions.

At the same time, the support of the Russian regions from the federal budget played an important role in the development of their tax base. Federal transfers to regional budgets, which increased from $19 \%$ in 2019 to $26 \%$ in 2020 (Zubarevich, 2021), largely offset the decline in the regions' own tax revenues. However, this support did not fit into the same rules for all regions; it was influenced not only by considerations of economic expediency, but also by political preferences. Meanwhile, this aid could have triggered an increase in incomes, primarily in the public sector, which contributed to the growth of tax revenues, for example, from personal income tax. This is contrary to what has happened in developed countries. The tightening budget constraints due to a decrease in fiscal revenues led to a reduction in employment in the state and municipal sectors, although in states that received more support, this effect was less (Green, Loualiche, 2021).

Our present study draws on works on both the resilience of regional economies to crises and the fiscal effects of the 2020 pandemic. Meanwhile, we note a lack of research related to identifying the impact of the coronavirus crisis on the resilience of both collected and own tax revenues of Russian regions and their decomposition by sources. This study aims to fill this gap. We also intend to explain the relationship between the structure of tax revenue losses/gains with the features of the sectoral structure of regional economies and the behaviour of various economic actors during the pandemic.

\section{Data and Methods}

The study is based on monthly data from the Federal Tax Service of the Russian Federation on tax revenues in 83 Russian regions (both consolidated and assigned to sub-federal budgets) in 2013-2020. Total and own tax revenues are broken down by 8 taxes and tax groups:

1) CIT - Corporate Income (Profit) Tax;

2) PIT - Personal Income Tax;

3) VAT - Value Added Tax;
4) Excises - excise taxes on alcohol, tobacco etc.;

5) PT - property taxes, including Personal Property Tax, Corporate Property Tax, Land Tax, Transport Tax, Gambling Tax, and special Real Estate Tax for the cities of Veliky Novgorod and Tver;

6) MET - natural resources taxes, a large proportion of which is Mineral Extraction Tax;

7) Duties - state fees;

8) STR - special tax regimes (United Agricultural Tax, Simplified Tax System, Presumptive Tax System, and since 2013 Patent Based Simplified Tax System), offering a range of benefits for the respective businesses. This group also includes the Production Sharing Agreement Tax System, which would be more correctly classified as taxes on natural resources.

The average structure of tax revenues and their variation in the regions in the prepandemic period of 2013-2019 is presented in Table 1 . In the period under review, $81.7 \%$ of all tax revenues in the country were provided by 4 taxes: MET, PIT, CIT and VAT. This structure changes after the distribution of taxes between the levels of the budgetary system according to the established rules. $83.2 \%$ of tax revenues of the federal budget consist of MET and VAT. Tax revenues in the sub-federal budgets by $70.8 \%$ are generated from PIT and CIT, and property taxes (PT) also make a significant contribution to them. The interregional standard deviation and coefficient of variation presented in Table 1 show that regional differences in the structure of tax revenues decrease with the transition from the consolidated level to the level of sub-federal budgets.

Next, we model tax revenues time series. The seasonality of economic activity and the different timing of payment of specific taxes cause intra-annual fluctuations in tax revenues. To eliminate these properties in monthly data, we compute a moving time series of annual tax revenues with a shift of one month.

Based on this revenues (TR) for December 2013 - March $2020(t=1, \overrightarrow{76})$, we build a temporary linear regression for each region:

$$
T R_{t}=\underbrace{\alpha_{0}+\alpha_{1} \cdot t}_{T \hat{R}_{t}}+e_{t}
$$


Table 1. Tax revenues structure and their regional differences in 2013-2019

\begin{tabular}{|c|c|c|c|c|c|c|c|c|c|}
\hline \multirow{2}{*}{} & \multicolumn{3}{|c|}{ Consolidated budget } & \multicolumn{3}{c|}{ Federal budget } & \multicolumn{3}{c|}{ Sub-federal budgets } \\
\cline { 2 - 11 } & Mean & StD & CV & Mean & StD & CV & Mean & StD & CV \\
\hline CIT & 19.3 & 9.1 & 0.47 & 8.1 & 73.6 & 9.04 & 31.0 & 8.8 & 0.28 \\
\hline PIT & 19.4 & 13.9 & 0.72 & 0.0 & 0.0 & - & 39.8 & 10.6 & 0.27 \\
\hline VAT & 17.8 & 14.3 & 0.80 & 34.8 & 125.3 & 3.60 & 0.0 & 0.0 & - \\
\hline Excises & 7.6 & 11.3 & 1.48 & 7.7 & 18.0 & 2.34 & 7.5 & 10.3 & 1.38 \\
\hline PT & 7.1 & 4.6 & 0.65 & 0.0 & 0.0 & - & 14.6 & 4.5 & 0.31 \\
\hline MET & 25.2 & 19.0 & 0.75 & 48.4 & 54.4 & 1.12 & 0.8 & 3.2 & 3.79 \\
\hline Duties & 0.2 & 0.2 & 1.07 & 0.2 & 10.3 & 53.67 & 0.2 & 0.2 & 0.76 \\
\hline STR & 3.3 & 4.3 & 1.30 & 0.8 & 4.7 & 6.17 & 6.0 & 4.1 & 0.68 \\
\hline Total & 100.0 & - & - & 100.0 & - & - & 100.0 & - & - \\
\hline
\end{tabular}

Note. Mean - average regional share in the country; StD - standard deviation of this share; CV - its coefficient of variation.

where $\alpha_{1}$ and $\alpha_{1}$ - estimates of regression coefficients, $T R_{t}$ - estimates of tax revenues, $e_{t}-$ regression residuals.

Similarly, we construct regressions for each $\mathrm{k}^{\text {th }} \operatorname{tax}(\operatorname{tax}$ group) in region:

$$
T R_{k t}=\underbrace{\alpha_{k 0}+\alpha_{k 1} \cdot t}_{T \hat{R}_{k t}}+e_{k t} .
$$

Since $T R_{t}=\sum_{k=1}^{K} T R_{k t}$, the additive property also holds for estimates and regression residuals: $\hat{T R}_{t}=\sum_{k=1}^{K} T \hat{R}_{k t} ; e_{t}=\sum_{k=1}^{K} e_{k t} ; \alpha_{0}=\sum_{k=1}^{K} \alpha_{k 0} ; \alpha_{1}=\sum_{k=1}^{K} \alpha_{k 1}$.

Based on these regressions, we predict smoothed tax revenues for April-December $2020(t=77,85)$. These are the values that could be expected if the previous trend persisted and there was no pandemic shock. The relative deviation of actual receipts $\left(T R_{t}\right.$ or $\left.T R_{k}\right)$ from predicted receipts $\left(T R_{t}\right.$ or $\left.T R_{k t}\right)$ shows the impact of the 2020 pandemic. It is determined based on the tax revenue level:

$$
I_{t}=\frac{T R_{t}}{\hat{T R}_{t}} \text {, and } I_{k t}=\frac{T R_{k t}}{T \hat{R}_{k t}} \text {. }
$$

The contribution of each tax to the change in tax revenue in the 2020 pandemic is calculated using the formula:

$$
\Delta T R \%(k)_{t}=\frac{T R_{k t}-T \hat{R}_{k t}}{\hat{T R}_{t}} .
$$

The structure of the losses (gains) of tax revenues:

$$
T R \%(k)_{t}=\frac{T R_{k t}-T \hat{R}_{k t}}{T R_{t}-\hat{T R_{t}}} .
$$

\section{Results and discussion}

Using the developed methodology, we obtained assessments of tax losses (gains) of Russian regions from the 2020 pandemic for the consolidated budget of the Russian Federation and sub-federal budgets and decomposed them by sources.

\section{A. Impact of the 2020 pandemic \\ on total tax collection in Russian regions.}

According to our calculations, the pandemic crisis resulted in a $13.9 \%$ loss of total tax revenue in the Russian Federation in 2020. With a forecast of $5.1 \%$ growth in tax revenues in 2020, their actual decrease relative to 2019 was $8.7 \%$. The period from April to July 2020 contributed the most to the decline in tax revenues, accounting for $10.2 \%$ of tax losses on an annualized basis. Meanwhile, the marginal effect of the pandemic was diminishing.

The change in tax revenues in the Russian regions was extremely uneven (Fig. 1). For 53 regions, the 2020 pandemic resulted in a shortfall in tax revenues, while 30 regions ended the fiscal year with revenue growth relative to the forecast. The greatest losses of tax revenues (over $50 \%$ ) are noted 


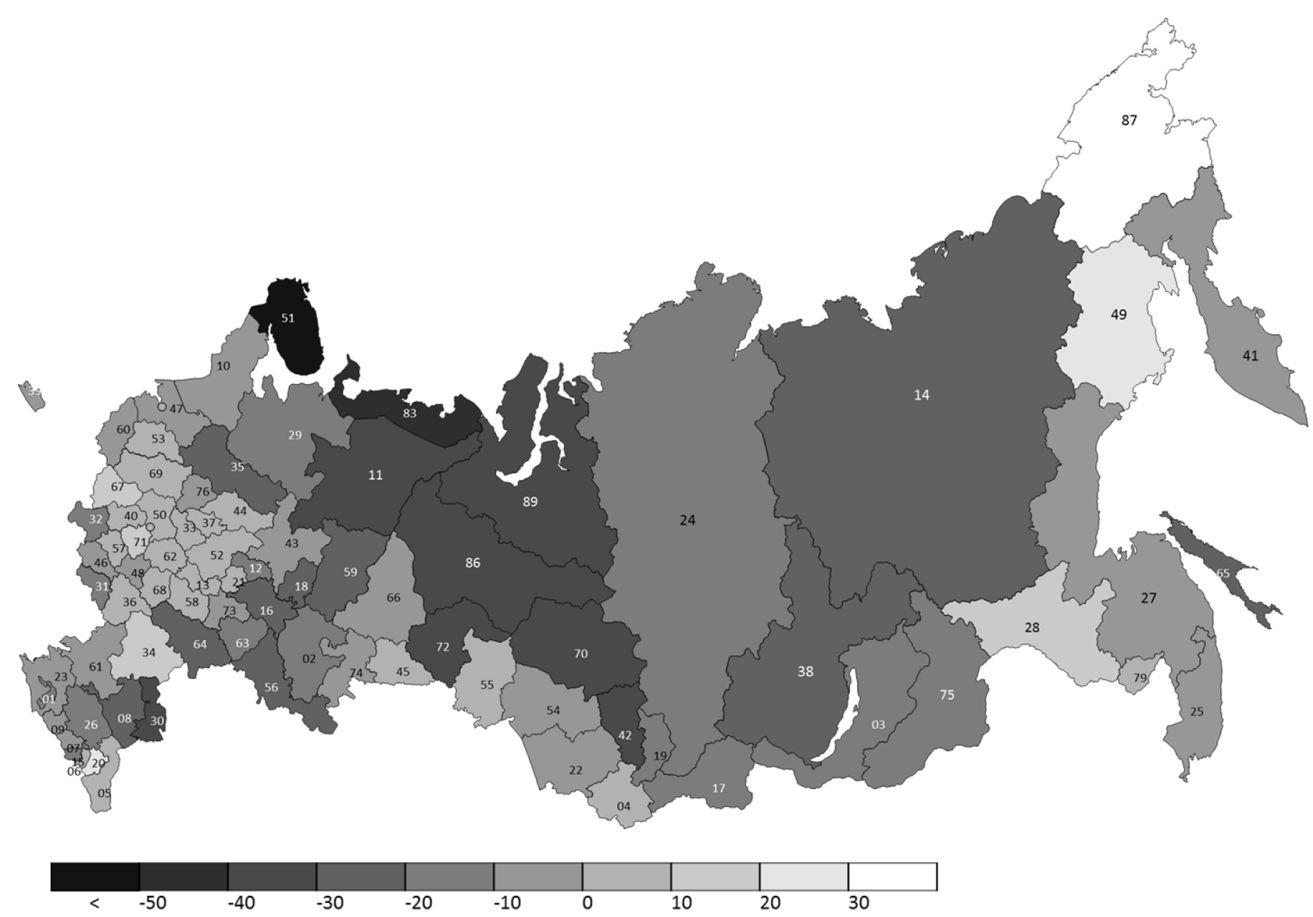

Fig. 1. Change in tax revenues of Russian regions to the RF consolidated budget in 2020,\%.

Note. Hereinafter, regions are designated by their administrative codes

in Murmansk region, mainly due to significant VAT refunds. Considerable decrease in tax revenues relative to the forecast values is also observed in many mining regions: Nenets Autonomous District (-44.4\%), Kemerovo region $(-36.8 \%)$, Tomsk region (-35.8\%), Khanty-Mansi Autonomous District $(-35.6 \%)$, Komi Republic (-33.8\%), Astrakhan region (-31.8\%), Yamalo-Nenets Autonomous District (-30.1\%), Tyumen region $(-30 \%)$. This is due to a noticeable drop in oil and gas prices and a contraction of their sales on the world and domestic markets.

At the same time, there was a significant increase in tax revenues in some Far Eastern regions: Chukotka Autonomous District (+37.7\%), Magadan region (+24.7\%), Amur region (+17.2\%), as well as in Chechen Republic $(+25.6 \%)$. One of the reasons for this may be significant transfers from the federal budget to these regions. Another possible reason is a significant increase in prices for non-ferrous metals, the production of which is located in the Far Eastern Federal District.
Figure 2 shows the results of decomposition of the country's tax revenue losses by various taxes. We see that the largest contribution to the reduction of tax revenues was made by natural resources taxes (MET). Over time, the impact of this tax only intensified, and by the end of the year it already accounted for $78.3 \%$ of the total drop in the country's tax revenues. Since the lion's share of MET is centralized, the risks of this tax were almost entirely borne by the federal budget of the Russian Federation. CIT was the second most important contributor to tax revenue loss. In various months, it provided from $19 \%$ to $26 \%$ of tax shortfalls in annual terms. The contribution of CIT to lower tax revenues has increased over time, although not as sharply as the contribution of MET.

The significant positive impact of VAT on tax revenues is evident in the early months of the pandemic, during strict lockdown. Thus, in April 2020, VAT accounted for $29.3 \%$ of the total increase in tax revenues, in May $-15 \%$, in June - only $9.3 \%$. By the end of the year, this positive effect practically disappeared, 


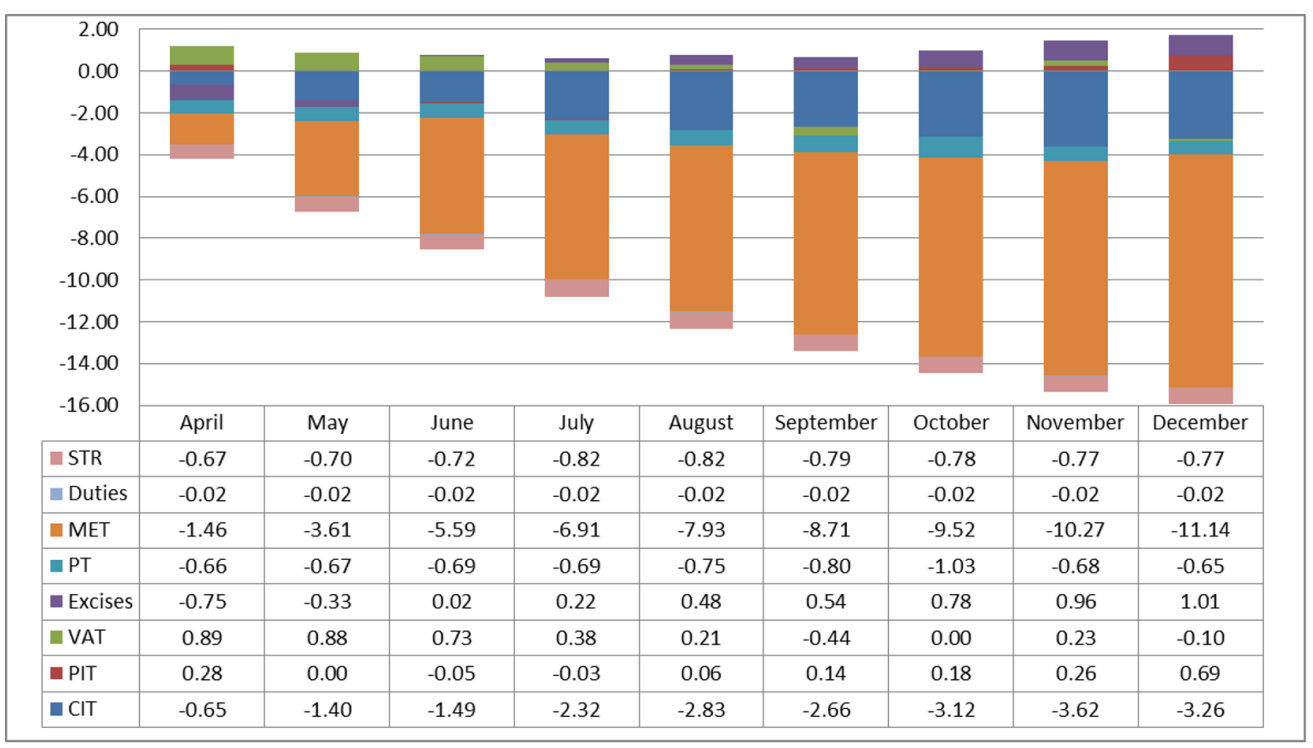

Fig. 2. Contribution of various taxes to the change in total tax revenues in the Russian Federation in the pandemic months of 2020 (on an accrual basis),\%

and, like most other taxes, VAT increased losses in the tax system, albeit insignificantly. We attribute initial positive VAT dynamics to consumer hype on the eve and in the first months of quarantine, which led to an increase in demand for food and everyday goods for future use, as well as medicines and means of protection, computer equipment for remote work, etc. The growth of VAT revenues may also be the result of increased domestic consumption due to limited external mobility.

Property taxes (PT) are autonomous, independent of the level of income in the economy. Therefore, they often play the role of automatic stabilizers during a crisis. Meanwhile, their decrease in the context of the coronavirus crisis can be explained by the introduction of corporate property tax incentives for small and medium-sized businesses and a number of industries recognized as the most affected by the 2020 pandemic. The contribution of PT to the reduction in the country's total tax revenue grew until November 2020, albeit their share in total tax losses became smaller (due to the greater influence of other taxes). Whereas in April 2020 they explained $21.8 \%$ of all tax losses, in May $-11.5 \%$, by the end of 2020 their contribution to the reduction of tax reve- nues was only $4.5 \%$, which is even lower than the PT share in total tax collections in the prepandemic period (Table 1).

Finally, the rise in excises and personal income tax (PIT) revenues indicates that they played a damper role during the pandemic crisis.

\section{A. Impact of the 2020 pandemic \\ on own tax revenues of sub-federal budgets.}

The distribution of taxes between budgetary system levels involves sharing their profitability and risk. As we noted earlier, the RF federal budget is formed of VAT, the lion's share of the MET, $3 \%$ of $20 \%$ CIT and deductions from a number of other less productive taxes. Thus, the federal budget took almost the entire risk of a $39.2 \%$ decrease in MET, but at the same time practically did not suffer from the VAT reduction. Sub-federal budgets respectively benefited from a slight increase in PIT $(+4.1 \%)$ and suffered from a noticeable decrease in CIT revenues $(-16.3 \%)$. In general, the tax distribution system played a positive role in reducing interregional differences. Indeed, the coefficient of variation for changes in own tax revenues of regional budgets is more than 2 times less than the coefficient of 
variation for changes in total tax revenues. The reduction in interregional inequality for tax losses at the sub-federal level is also noticeable when comparing Fig. 1 and 3.

The decrease in own tax revenues of subfederal budgets across the country amounted to only $6.2 \%$ (against a $13.9 \%$ decline in total tax collections). For the sub-federal tax revenues, we do not observe extremely large losses in some regions (Fig. 3), which were typical for total tax collections (Fig. 1). Meanwhile, the largest decrease in own tax revenues is still marked in the mining regions: Tyumen Region (-28.3\%), Nenets Autonomous District (-28.1\%), Kemerovo Region $(-27.7 \%)$, Yamalo-Nenets Autonomous District $(-25.6 \%)$, Komi Republic (-23.6 \%). A large loss of tax revenues is also noted in the lagging Republic of Khakassia (-25.9\%).

In general, a negative increase in own tax revenues is observed in 62 Russian regions (which is more than at the stage of tax collection). However, in this group, two-thirds (41) are regions with tax losses of no more than $10 \%$. In another 15 regions, tax revenues fell by no more than $20 \%$. The number of regions with positive dynamics of tax revenues to subfederal budgets is only 21 (versus 30 for total tax revenues). However, in most of these regions (17), the surplus of tax revenues does not exceed $10 \%$.

Figure 4 shows the results of the decomposition of changes in tax revenues to subfederal budgets by types of taxes. The losses of sub-federal budgets are largely attributed to a drop in CIT revenues. While in April 2020 this tax accounted for $56.6 \%$ of the total decrease in tax revenues to sub-federal budgets, by December 2020 its contribution increased to $94.2 \%$. On average, CIT explains $5.8 \%$ of the $6.2 \%$ decline in regional tax revenues compared to the non-pandemic forecast. This is the result of the deterioration in the financial performance of enterprises due to the decline in production.

Property taxes also played a significant role in reducing tax revenues of sub-federal budgets. In 2020, they accounted for $23.4 \%$ of all tax losses, which is more than 3 times greater than their share in total tax revenue (Ta-

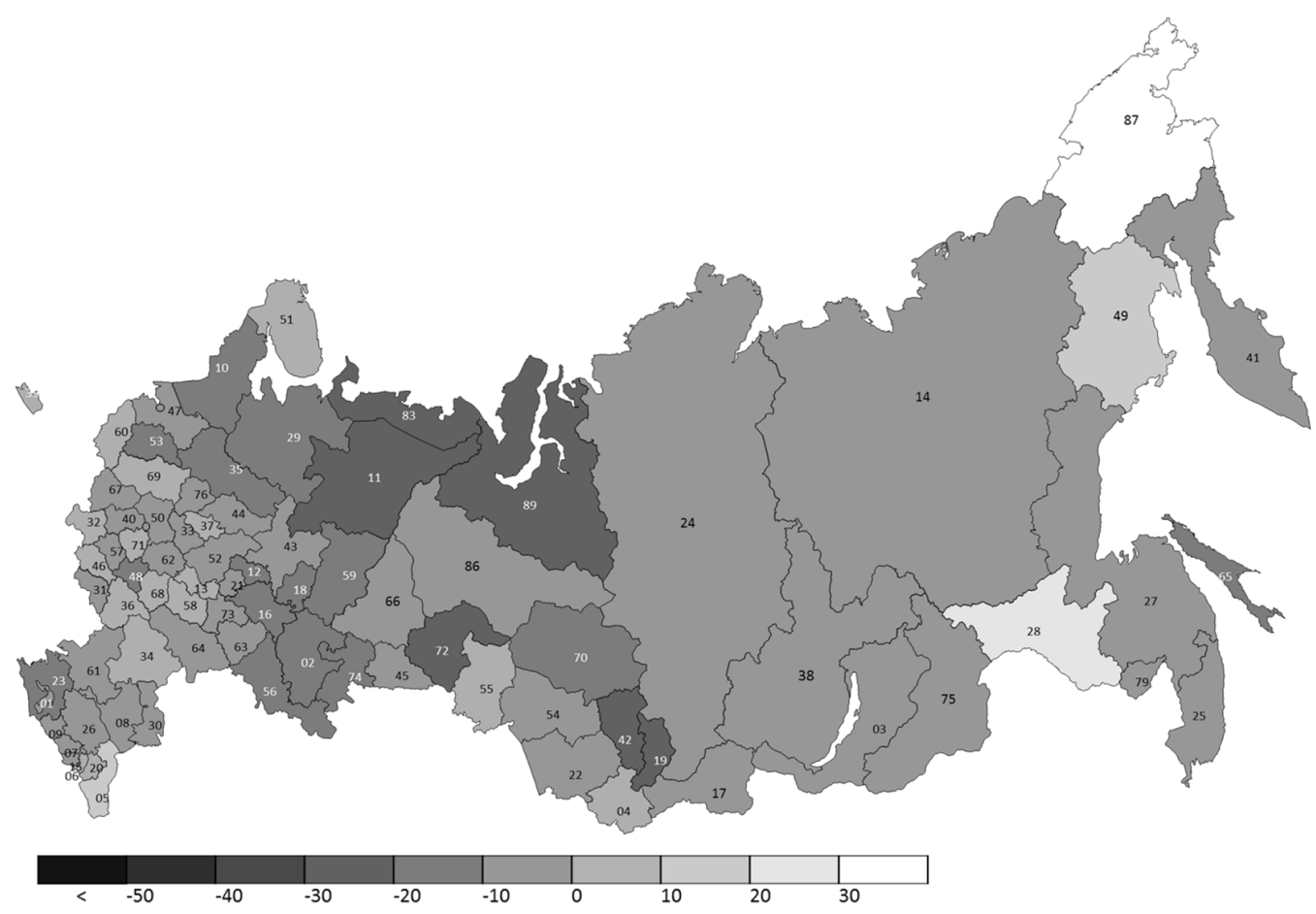

Fig. 3. Change in tax revenues of Russian regions to sub-federal budgets in $2020, \%$ 


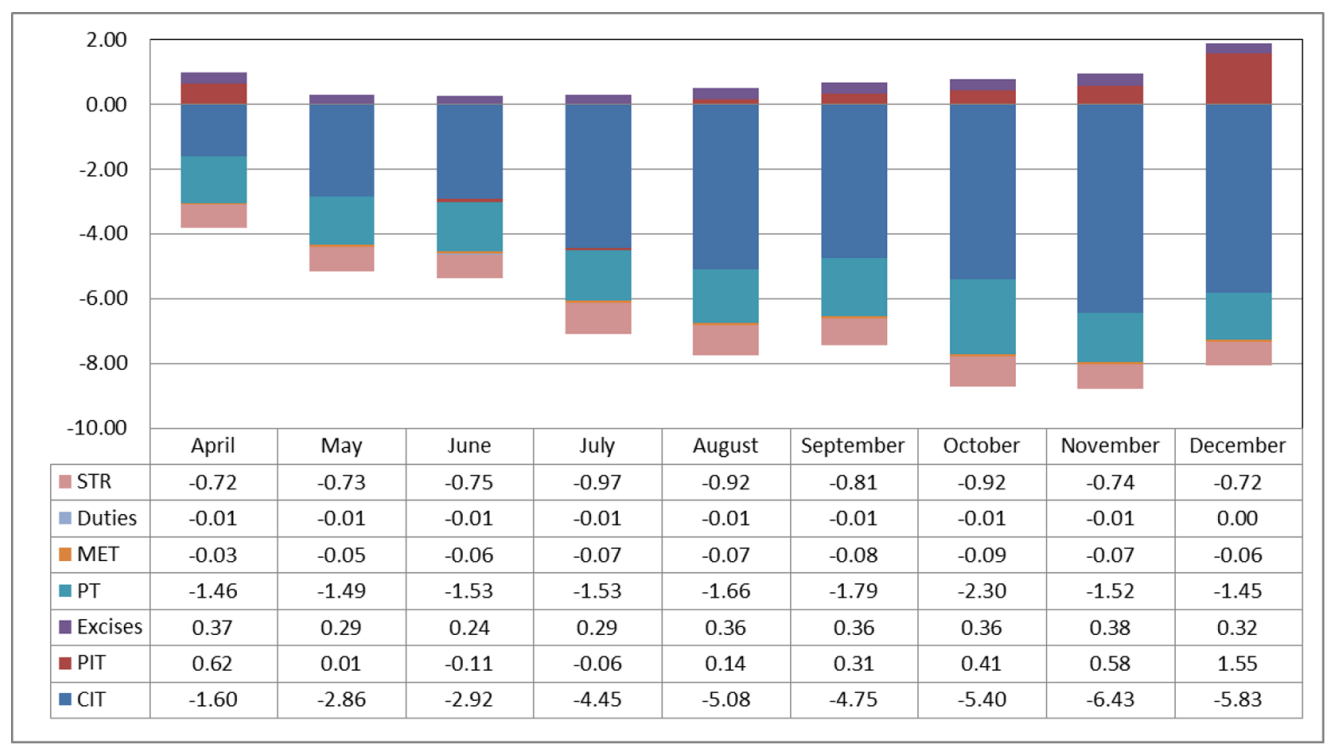

Fig. 4. Contribution of various taxes to changes in tax revenues to the budgets of the constituent entities of the Russian Federation in the pandemic months of 2020 (on an accrual basis), \%

ble 1). Their contribution to the loss of tax revenues in Russian regions gradually increased from April to October 2020, but in the last two months of 2020 actually returned to the level of the first month of the pandemic.

Incomes from special tax regimes were the third most important source of falling tax revenues of sub-federal budgets. They are responsible for $11.6 \%$ of all tax losses of the regions in 2020. Their contribution to the reduction of tax revenues follows the same pattern as the contribution of property taxes.

At the same time, we should emphasize the positive impact of the other two groups of taxes (personal income tax and excise taxes) on increasing tax revenues during the 2020 pandemic. Unlike the stage of tax collections, at the stage of tax allocation to sub-federal budgets, the impact of excise taxes on the growth of the regions' own tax revenues was less than the impact of PIT, and it was relatively stable over time. The influence of PIT on changes in the regions' own incomes was much more significant and growing over time. As a result, by the end of 2020, PIT compensated for almost a quarter of the losses of Russian regions from other taxes.
Additional revenue from excise taxes on gasoline and diesel in 2020 is associated with an increase in VAT and a revision of tax rates. The growth of excise tax receipts from wine \& vodka, and tobacco products can be explained by both an increase in tax rates and a change in consumer preferences during the pandemic. The PIT gains are attributed to enlarged federal transfers to Russian regions and rising wages in the state and municipal sectors.

\section{Conclusion}

The study is devoted to identifying the impact of the 2020 pandemic on the change in tax revenues in the Russian regions before and after their distribution between the levels of the budgetary system, as well as determining the contribution of various taxes and tax groups to this change. To achieve this goal, we have proposed and implemented a method for forecasting tax revenues in the regions and their decomposition by sources.

Our study shows that the decline in total tax revenues during the pandemic (relative to the non-pandemic forecast) was $13.9 \%$, while the relative losses of regional budgets were less than half of that $(6.2 \%)$. In other words, the 
federal budget has taken on most of the pandemic's tax risks.

At the consolidated level, the largest and ever increasing share of losses accrued to the mineral extraction tax (due to falling world oil prices and its sales). Therefore, the tax systems of the extractive regions were the most affected by the pandemic. The corporate income (profit) tax also made a significant contribution to the decrease in tax revenues, while property taxes had a lesser impact (mainly due to the establishment of tax incentives for corporate property). Initially, VAT revenues grew amid consumer excitement, but then their dynamics stabilized. The increase in excise taxes and personal income tax partially offset the losses from other taxes. We associate the positive dynamics of personal income tax with active government support for certain industries and regions, and the growth of wages in the state and municipal sectors. At the same time, a significant increase in excise taxes was due to the changes in tax rates and consumer habits during the pandemic.

The Russian tax sharing system demonstrated a positive impact on reducing interregional disparities and increasing the resilience of regions to crisis. The main role in this was played by the payment of most of the mineral extraction tax to the federal budget. On the one hand, the number of regions with negative dynamics of their own tax revenues turned out to be greater than the number of regions with negative growth in total tax revenues. On the other hand, inter-regional differences in tax losses / benefits at the sub-federal level are significantly lower than at the consolidated level. In the context of the 2020 pandemic, the corporate income tax had the greatest negative impact on tax revenues to regional budgets. Property taxes and revenues from special tax regimes made a much smaller contribution to tax losses. Personal income tax turned out to be the main damper of tax revenues at the regional level, and excise taxes played a lesser positive role.

The results obtained can be useful for managing the fiscal revenues of the state during pandemic-driven crises. The limitations of the study are related to the income forecasting methodology based on linear extrapolation of time dependences, as well as the difficulties in identifying the influence of institutional factors on tax revenues (associated with both changes in formal rules and «manual control» in the Russian fiscal system). The future work on the study can be focused on elaboration of methods for forecasting taxes, taking into account the influencing factors, and in a deeper explanation of the reaction of the regional tax systems to the pandemic crisis.

\section{References}

Brada, J.C., Gajewski, P., Kutan, A.M. (2021). Economic resiliency and recovery, lessons from the financial crisis for the COVID-19 pandemic: A regional perspective from Central and Eastern Europe. In International Review of Financial Analysis, 74, 101658. DOI: 10.1016/j.irfa.2021.101658.

Chakrabarty, H.S., Roy, R.P. (2021). Pandemic uncertainties and fiscal procyclicality: A dynamic non-linear approach. In International Review of Economics \& Finance, 72, 664-671. DOI: 10.1016/j. iref.2020.12.027.

Chernick, H., Copeland, D., Reschovsky, A. (2020). The fiscal effects of the covid-19 pandemic on cities. An initial assessment. In National Tax Journal, 73(3), 699-732. DOI: 10.17310/ntj.2020.3.04.

Clemens, J., Veuger S. (2020). Implications of the Covid-19 pandemic for state government tax revenues. In National Tax Journal, 73(3), 619-644. DOI: 10.17310/ntj.2020.3.01.

Darougheh, S. (2021). Dispersed consumption versus compressed output: Assessing the sectoral effects of a pandemic. In Journal of Macroeconomics, 103302. DOI: 10.1016/j.jmacro.2021.103302.

Ershov, M.V. (2020). Mir v 2020 godu: novye problemy obnazhaiut sistemnye izmeneniia v ekonomike [The world in 2020: new challenges expose systemic changes in the economy]. In Voprosy Ekonomiki [Issues of Economics], 12, 5-23. DOI: 10.32609/0042-8736-2020-12-5-23.

Green, D., Loualiche, E. (2021). State and local government employment in the COVID-19 crisis. In Journal of Public Economics, 193, 104321. DOI: 10.1016/j.jpubeco.2020.104321. 
Gunay, S., Kurtulmuş, B.E. (2021). COVID-19 social distancing and the US service sector: What do we learn? In Research in International Business and Finance, 56, 101361. DOI: 10.1016/j.ribaf.2020.101361.

Hoehn-Velasco, L., Silverio-Murillo, A., de la Miyar, J.R.B. (2021). The long downturn: The impact of the great lockdown on formal employment. In Journal of Economics and Business, 105983. DOI: 10.1016/j. jeconbus.2021.105983.

Keane, M., Neal, T. (2021). Consumer panic in the COVID-19 pandemic. In Journal of Econometrics, 220 (1), 86-105. DOI: 10.1016/j.jeconom.2020.07.045.

Klimanov, V., Kazakova, S., Mikhaylova, A. and Safina, A. (2021). Fiscal resilience of Russia's regions in the face of COVID-19. In Journal of Public Budgeting, Accounting \& Financial Management, 33(1), 87-94. DOI: 10.1108/JPBAFM-07-2020-0123.

Kolomak, E. (2020). Economic effects of pandemic-related restrictions in Russia and their spatial heterogeneity. In R-Economy, 6(3), 154-161. DOI: 10.15826/recon.2020.6.3.013.

Kuznetsova, O.V. (2020). Uiazvimost' struktury regional'nykh ekonomik v krizisnykh usloviiah [Vulnerability of regional economies' structure in crisis conditions]. In Federalism, 2(98), 20-38. Doi: 10.21686/2073-1051-2020-2-20-38.

Makin, A.J., Layton, A. (2021). The global fiscal response to COVID-19: Risks and repercussions. In Economic Analysis and Policy, 69, 340-349. DOI: 10.1016/j.eap.2020.12.016.

Malkina, M. Iu. (2020). Otsenka ustoichivosti razvitiia regional'nykh ekonomik na osnove rasstoianii Mahalanobisa [Assessment of resilient development of the regional economies based on Mahalanobis distances]. In Terra Economicus, 18(3), 140-159. DOI: 10.18522/2073-6606-2020-18-3-140-159.

Mikheeva, N.N. (2021). Resilience of Russian Regions to Economic Shocks. In Studies on Russian Economic Development, 32 (1), 68-77. DOI: 10.1134/S107570072101010X

Pietro, F. D., Lecca, P., Salotti, S. (2020). Regional economic resilience in the European Union: a numerical general equilibrium analysis. In Spatial Economic Analysis, DOI: 10.1080/17421772.2020.1846768.

Zubarevich, N.V. (2021). Vliianie pandemii na sotsial'no-ekonomicheskoe razvitie i biudzhety regionov [The pandemic's influence at socio-economic development and regional budgets]. In Voprosy teoreticheskoi ekonomiki [Issues of Theoretical Ecoomics], 1, 48-60. DOI: 10.24411/2587-7666-2021-10104. 